\title{
Microcurie per Liter
}

National Cancer Institute

\section{Source}

National Cancer Institute. Microcurie per Liter. NCI Thesaurus. Code C71173.

A unit of volumetric radioactivity concentration defined as a concentration of a

radionuclide with an activity equal to one millionth of a curie per unit volume equal to one liter. 